\title{
SYNTHESIS AND THERMAL ANALYSIS OF POLYESTERS HAVING SPIRO-DIOXANE RINGS AND GUAIACYL UNITS
}

\author{
By Shigeo Hirose ${ }^{* 1}$, Tatsuko Hatakeyama ${ }^{* 2}$ \\ and Hyoe Hatakeyama ${ }^{* 1}$ \\ -1 (Industrial Products Research Institute, 1-1-4, Yatabe-Higashi, \\ Tsukuba, Ibaraki 305, Japan) \\ -2 (Research Institute for Polymers and Textiles, 1-1-4, Yatabe- \\ Higashi, Tsukuba, Ibaraki 305, Japan)
}

\section{INTRODUCTION}

Vanillin, 4-hydroxy-3-methoxybenzaldehyde, industrially obtained by oxidative degradation of lignin, has two reactive functional groups, and is easily converted to various derivatives. Therefore, the use of vanillin as a raw material for synthetic polymers has been attempted by several researchers ${ }^{1,2)}$ since the 1950's when Bock et al. ${ }^{3,4)}$ developed polyesters.

In recent years, we have studied synthetic polymers obtained from lignin related phenol derivatives with respect to the relationship between the chemical structure and physical properties. Studies on poly(4-hydroxy-3-methoxystyrene) ${ }^{5-9}$ ) and poly(oxy-2-methoxy-1,4-phenylenecarbonylmethylene) ${ }^{10)}$ have been reported in detail elsewhere.

Recently, 3,9-bis(4-hydroxy-3-methoxyphenyl)2,4,8,10-tetraoxa-spiro[5.5] undecane, designated bisphenol (1), which contains a spiro-dioxane ring, was synthesized, and polyesters were obtained through reactions with terephthaloyl or sebacoyl chloride. In the present paper, synthesis and some thermal properties of these polyesters are discussed in relation to their chemical structure.

\section{EXPERIMENTAL}

\subsection{Materials}

Vanillin and pentaerythritol, reagent grade, were obtained commercially and used as received. Commercially obtained terephthaloyl chloride and sebacoyl chloride were purified by recrystallization from benzene and distillation under reduced pressure, respectively.

Dichloromethane was purified and dried by distillation over phosphorous pentoxide.

\subsection{Synthesis}

\subsubsection{Synthesis of 3,9-bis (4-hydroxy-3-methoxy-} phenyl)-2,4,8,10-tetraoxa-spiro[5.5] undecane (I)

Vanillin $(7.5 \mathrm{~g})$, pentaerythritol $(3.4 \mathrm{~g})$ and $p$ toluenesulfonic acid monohydrate $(0.60 \mathrm{~g})$ were dissolved in benzene $(150 \mathrm{ml})$ and refluxed for $4 \mathrm{hr}$. Water formed during the reaction was removed by a Dean-Stark trap. After cooling to room temperature, the reaction mixture was washed with aqueous alkaline solution of sodium carbonate $(0.34 \mathrm{~g}) /$ water $(100 \mathrm{ml})$ and then with water. After drying with sodium sulfate, the reaction mixture was concentrated under reduced pressure. A precipitate was obtained by addition of ethyl ether to the above reaction mixture. The precipitate was then collected and recrystallized from toluene. Yield was $4.50 \mathrm{~g}(50 \%)$, mp $169-171^{\circ} \mathrm{C}$ (colorless needles). IR $(\mathrm{KBr}), \mathrm{cm}^{-1}: 3325(-\mathrm{OH}), 1610$, 1520 (phenyl, $\mathrm{C}-\mathrm{H}$ ). NMR ( $\left.\mathrm{CDCl}_{3}, \mathrm{TMS}\right), \delta \mathrm{ppm}$ : $3.54-4.07\left(6 \mathrm{H}, \mathrm{m},-\mathrm{CH}_{2}-,-\mathrm{C} \underline{\mathrm{H}}(\mathrm{H})-\right), 4.00$ $\left(6 \mathrm{H}, \mathrm{s}, \mathrm{Ar}-\mathrm{OCH}_{3}\right), 4.37-5.10(2 \mathrm{H}, \mathrm{d},-\mathrm{CH}(\mathrm{H})-)$, $5.47(2 \mathrm{H}, \mathrm{s}, \mathrm{Ar}-\mathrm{OH}), 5.77(2 \mathrm{H}, \mathrm{s}, \mathrm{Ar}-\mathrm{CH}), 6.97-$ $7.45(6 \mathrm{H}, \mathrm{m}, \mathrm{Ar})$.

Anal. Calcd for $\mathrm{C}_{21} \mathrm{H}_{24} \mathrm{O}_{8}: \mathrm{C}, 62.37 ; \mathrm{H}, 5.98$. Found: $\mathrm{C}, 62.4 ; \mathrm{H}, 6.0$.

\subsubsection{Synthesis of polyesters}

Polymerization was carried out as follows. A dichloromethane solution $(5 \mathrm{~m})$ ) of terephthaloyl chloride $(0.305 \mathrm{~g})$ was added to dichloromethane $(10 \mathrm{ml})$ containing bisphenol (I) $(0.607 \mathrm{~g})$ and 
triethylamine $(0.45 \mathrm{ml})$. This mixture was mechanically stirred for $24 \mathrm{hr}$ at room temperature. The reaction mixture obtained was added to methanol $(400 \mathrm{ml})$. The precipitate formed was collected and washed with methanol. Purification of the polymer was carried out by reprecipitation using $m$-cresol and methanol. Yield was $0.743 \mathrm{~g}(92.7 \%)$. IR ( $\mathrm{KBr}$ ). $\mathrm{cm}^{-1}: 1740$ (ester, $\mathrm{C}=\mathrm{O}$ ).

Anal. Calcd for $\mathrm{C}_{29} \mathrm{H}_{26} \mathrm{O}_{10}$ : C, 65.16; $\mathrm{H}, 4.90$. Found: C, 65.0; H, 4.9.

Polysebacate was also obtained through a similar procedure using sebacoyl chloride instead of terephthaloyl chloride. Yield was $93.7 \%$. IR $(\mathrm{KBr}), \mathrm{cm}^{-1}: 1760$ (ester, $\mathrm{C}=\mathrm{O}$ ).

Anal. Calcd for $\mathrm{C}_{31} \mathrm{H}_{38} \mathrm{O}_{10}: \mathrm{C}, 65.25 ; \mathrm{H}, 6.71$. Found; C, 65.1; H, 6.7.

\subsection{Measurements}

Infrared spectra were obtained with a JEOL A-3 spectrometer. A NMR spectrum was measured with a Varian EM-360 spectrometer. Heat capacities were determined using a Perkin-Elmer differential scanning calorimeter (DSC) model DSC-II equipped with a Textronix 31 calculater. A sensitivity of $2 \mathrm{mcal} / \mathrm{sec}$ and heating rate of $10 \mathrm{~K} / \mathrm{min}$ was used. Thermogravimetric measurement was carried out using a Shimazu TGA-30M thermogravimeter. X-ray diffractograms were obtained with a Rigaku Denki model 2171 X-ray diffractometer.

\section{RESULTS AND DISCUSSION}

\subsection{Synthesis}

Conrad et al. ${ }^{11)}$ reported the synthesis of mono- and bis-acetals and ketals by the reactions of pentaerythritol with aldehydes and ketones in benzene with a catalytic amount of p-toluenesulfonic acid. Therefore, in the present study, bisphenol (I) was synthesized by a method similar to that reported.

As illustrated in scheme 1, bisphenol (I) was synthesized from vanillin and pentaerythritol in benzene with the addition of a catalytic amount of $p$-toluenesulfonic acid, using a Dean-Stark trap to remove water.

Polyesters were obtained by the reaction of bisphenol (I) with terephthaloyl chloride or sebacoyl chloride in chloroform using triethylamine as an acid acceptor. The yields and the inherent viscosities of polyesters are shown in Table 1. As seen here, polyesters having high $\eta_{\text {inh }}$ 's could be obtained. These polyesters dissolved in $\mathrm{m}$-cresol

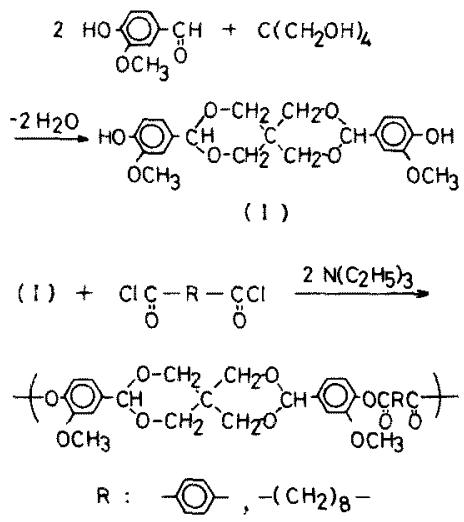

Scheme 1

Table 1. Properties of obtained polymers.

\begin{tabular}{|c|c|c|c|c|c|}
\hline Polyester & $\begin{array}{c}\text { Yield } \\
\%\end{array}$ & $\begin{array}{l}\eta_{\mathrm{inh}}{ }^{\text {a) }} \\
\mathrm{d} \mathrm{l} / \mathrm{g}\end{array}$ & $\begin{array}{l}\text { Heating } \\
\text { Rate } \\
\mathrm{K} / \mathrm{min}\end{array}$ & $\begin{array}{l}T_{g} \\
\mathrm{~K}\end{array}$ & $\begin{array}{l}T_{d}{ }^{\mathrm{c})} \\
\mathrm{K}\end{array}$ \\
\hline \multirow[t]{6}{*}{ Polysebacate } & 93.7 & 0.89 & $0^{\text {b) }}$ & 358 & \\
\hline & & & 2.5 & 359 & \\
\hline & & & 5 & 361 & \\
\hline & & & 10 & 363 & \\
\hline & & & 20 & 366 & 527 \\
\hline & & & 40 & 369 & \\
\hline Polyterephthalate & 92.7 & 1.30 & 20 & not found & 568 \\
\hline
\end{tabular}

a) Measured at a concentration of $0.125 \mathrm{~g} / \mathrm{dl}$ in $\mathrm{m}$-cresol at $30^{\circ} \mathrm{C}$

b) $T_{g}$ obtained by extrapolation of heating rate to zero

c) Measured in nitrogen 
and $o$-chlorophenol. However, they did not dissolve in $\mathrm{N}, \mathrm{N}$-dimethylformamide, dimethyl sulfoxide or chloroform.

\subsection{Thermal Analysis}

The thermal stability of the obtained polyesters, polyterephthalate (PTS) and polysebacate (PSS) having spiro-dioxane rings, was analyzed by thermogravimetry (TG). Fig. 1 shows TG curves of the polyesters measured in an atmosphere of purified nitrogen. PTS started to decompose at $568 \mathrm{~K}$ and PSS at $527 \mathrm{~K}$. This shows that the former is thermally more stable than the latter.

DSC studies of the above polymers were carried out in an atmosphere of nitrogen at the heating rate $10 \mathrm{~K} / \mathrm{min}$ from room temperature to a temperature, a few Kelvins below the thermal decomposition temperature $\left(T_{d}\right)$ determined by TG (see Table 1). Although no transition was detected in the DSC curve of PTS, a glass transition at 363K was seen in that of PSS. $T_{g}$ 's of PSS measured at various heating rates are shown in Table 1.

The X-ray diffractogram of PTS showed a crystalline pattern while that of PSS showed an amorphous halo pattern.

One of the purpose of the present study is to investigate the relationship between the properties and structure of these polymers. Generally speaking, as $T_{g}$ value of a polymer depends on its rigidity, it should be possible to estimate the rigidity of the spiro-dioxane rings in PSS by comparing the $T_{g}$ with those of polysebacates from other bisphenolic compounds.

Among the polyesters from bisphenolic compounds, the thermal properties of polyesters from

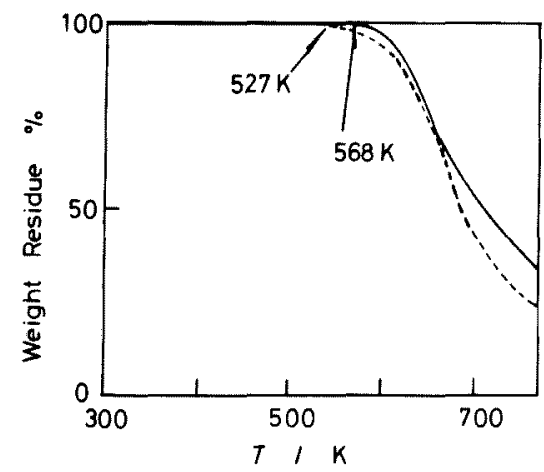

Fig. 1 TG curves of polyterephthalate (PTS) and polysebacate (PSS). ㄴ. : PTS, -..... : PSS. di-substituted bis(4-hydroxyphenyl)methane have been studied in detail. Therefore, we attempted to compare the $T_{g}$ of PSS with those of a series of polyesters obtained from di-substituted bis(4hydroxyphenyl)methane ${ }^{12)}$. which have threedimensional connecting units such as 1 or $1 \mathrm{O}$ (B), and their thermal properties have been studied in detail, respectively. The reported $T_{g}$ 's of polysebacates (A) and (B) are 424 , and $417 \mathrm{~K}$. Therefore, the difference between the chemical structures of PSS and (A) or (B) is that PSS has a spiro-dioxane ring and methoxyl groups at the 3-position of each aromatic ring while (A) and (B) lack these structural features. The $\eta_{\text {inh }}$ of PSS is 0.89 and those of (A) and (B) are reported as 0.73 and $1.03^{12)}$, respectively. Therefore, we may consider the molecular weights of the above polymers to be not very much different. As reported previously ${ }^{7}$, the presence of a methoxyl group on the aromatic ring increases molecular mobility. As is clearly seen, the $T_{g}$ of PSS is almost $60 \mathrm{~K}$ lower than those of $(\mathrm{A})$ and (B). On the other hand, the $T_{g}$ of polysebacate from 2,2-bis(4-hydroxyphenyl)propane ${ }^{13)}$ was reported to be $280 \mathrm{~K}$ which is significantly lower than that of PSS. Therefore, if we consider the effect of the methoxyl groups, which bring about a decrease in the $T_{g}$ of the polymers, it may be reasonable to assume that the rigidity of the spiro-dioxane ring is almost similar to those of $(A)$ and (B), even though the $T_{\mathrm{g}}$ of PSS is almost $60 \mathrm{~K}$ lower than those of (A) and (B).

As mentioned above, no transition was detected in the polyester PTS by DSC measurements. Therefore, for the purpose of comparing the thermal stability of PTS and PSS, we measured the heat capacity $\left(C_{p}\right)$ of both polymers in the temperature range $352 \mathrm{~K}$ to $386 \mathrm{~K}$. As seen from Table 2 and Fig. 2, the $C_{p}$ of PTS is lower than that of PSS. This indicates that the thermal stability of PTS is greater than that of PSS. This fact also agrees well with the results shown that the $T_{d}$ of PTS is higher than that of PSS.

\section{Acknowledgment}

Authors are grateful to Mr. Marc Lamphier for his helpful assistance in preparing the manuscript. 
Table 2. Heat capacities of polyterephthalate (PTS) and polysebacate (PSS) polymers.

\begin{tabular}{ccccccc}
\hline \multirow{2}{*}{ Temp. } & \multicolumn{2}{c}{$C_{p}, \mathrm{~J} /$ deg $\mathrm{g}$} & & Temp. & \multicolumn{2}{c}{$C_{p}, \mathrm{~J} /$ deg g } \\
\cline { 2 - 3 } \cline { 5 - 6 } $\mathrm{K}$ & PTS & PSS & & $\mathrm{K}$ & PTS & PSS \\
\hline 352 & 1.271 & 1.515 & & 370 & 1.350 & 1.761 \\
354 & 1.285 & 1.534 & & 372 & 1.357 & 1.858 \\
356 & 1.294 & 1.546 & & 374 & 1.366 & 1.859 \\
358 & 1.304 & 1.563 & & 376 & 1.374 & 1.848 \\
360 & 1.310 & 1.580 & & 378 & 1.380 & 1.853 \\
362 & 1.316 & 1.600 & & 380 & 1.385 & 1.860 \\
364 & 1.327 & 1.627 & & 382 & 1.390 & 1.862 \\
366 & 1.333 & 1.665 & & 384 & 1.394 & 1.870 \\
368 & 1.344 & 1.720 & & 386 & 1.403 & 1.881 \\
\hline
\end{tabular}

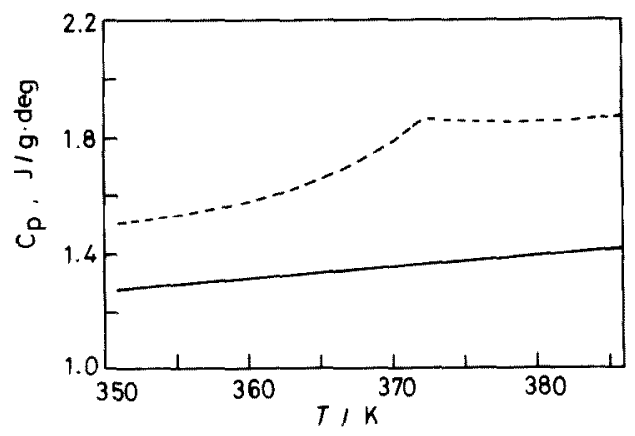

Fig. 2 Heat capacities of polyterephthalate (PTS) and polysebacate (PSS). - : PTS, -..-.: PSS.

\section{REFERENCES}

1) S. Takamuku and Y. Hachihama, Kogyo Kagaku Zasshi, 61, 1097 (1958)

2) B. Malm, Makromol. Chem., 182, 1307 (1981)

3) L. H. Bock and J. K. Anderson, J. Polym. Sci., 17, 553 (1955)
4) L. H. Bock and J. K. Anderson, J. Polym. Sci., 28, 121 (1958)

5) T. Hatakeyama, K. Nakamura and H. Hatakeyama, Polymer, 19, 593 (1978)

6) K. Nakamura, T. Hatakeyama and H. Hatakeyama, Polymer, 22, 473 (1981)

7) H. Hatakeyama, K. Nakamura and T. Hatakeyama, Transactions, Pulp and Paper Association, Canada, 81, TR 105 (1981)

8) T. Hatakeyama and H. Hatakeyama, Polymer, 23, 475 (1982)

9) H. Hatakeyama, S. Hirose, K. Kasuga and T. Hatakeyama, Proceeding of the Ekman-Days 1981, International Symposium on Wood and Pulping Chemistry, Stockholm, June, Vol 4, pp. 96

10) S. Hirose, T. Hatakeyama and H. Hatakeyama, Cellulose Chem. Technol., 12, 713 (1978)

11) W. E. Conrad, B. D. Gesner, L. A. Levasseur, R. F. Murphy and H. M. Conrad, J. Org. Chem, 26, 3571 (1961)

12) P.W. Morgan, Macromolecules, 3, 536 (1970)

13) G. P. Mikhailov and M.P. Eidl'nant, Vysokomol. Soedin., 2, 287 (1960)

スピロジオキサン環とグアヤシル基を有する

ポリエステルの合成およびその熱的性質

\section{製品科学研究所 \\ 繊維高分子材料研究所 \\ 製品科学研究所 \\ 㕕瀬重雄 \\ 泉山立子 \\ 皇山兵衛}

バニリンとペンタエリスリトールを原料しして、スピ ロシオキサン疅を有する 3.9 -ビス（4-ヒドロキシー3-メ トキシフェニル)-2,4,8,10-テトラオキサスピロ[5.5] ウンデカン(1)を合成した。さらに，ビスフェノール(1)
からポリテレフタレート(PTS)及びポリセバケート (PSS) を合成した。

X線回折測定によりPTSは結晶性であり，PSSは無 定形であるるとどわかった。さらに，熱重量分析の結果， 
PTSおよびPSSの熱分解温度は，それぞれ，568K拉 よび527Kであり，PTSのちが熱的に安定であった。

また，示差走查熱㻎計による分析では，PTSは昇温 测定により相転移は認的られなかったが，PSSは363 Kにガラス転栘 $\left(T_{g}\right)$ が認施れた。 PSSのT $T_{g}$ し，す

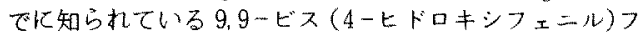

ルオレンあるいは 9,9ービス(4一ヒドロキシフェール) 一 9.10-ジヒドロアントラセンのポリセバケートの $T_{g}$ と 比較老行い，スピロジオキサン環の㓮直性老推定した。

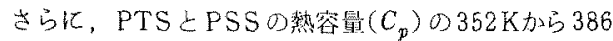
Kの渭度籍罒で測定し，PTSの $C_{p}$ が低いとよから，を の熱的安定性のよいこと老明ら加にた。 